\title{
Palynofacies analysis of Ida-4 well, Niger Delta Basin, Nigeria
}

\author{
Jacinta Nkiru Chukwuma-Orji, Edward Agboneni Okosun, \\ Funmilayo Daramola Gana
}

${ }^{1}$ Federal University of Technology, Department of Geology; Minna, Niger State, Nigeria; e-mail: jacinta@futminna.edu.ng;
ORCID ID: 0000-0001-9541-2566
${ }^{2}$ Federal University of Technology, Department of Geology; Minna, Niger State, Nigeria; e-mail: eaokosun@futminna.edu.ng
${ }^{3}$ Federal University of Technology, Department of Geology; Minna, Niger State, Nigeria; e-mail: ganafunmilayo@gmail.com

(c) 2019 Authors. This is an open access publication, which can be used, distributed and reproduced in any medium according to the Creative Commons CC-BY 4.0 License requiring that the original work has been properly cited.

Received: 25 January 2019, accepted: 12 September 2019; first published online: 18 November 2019

\begin{abstract}
Palynofacies analyses of the strata penetrated by Ida-4 wells were carried out with the aim of studying the stratigraphic sequence penetrated by the well in order to establish palynostratigraphic zones, relative age and the paleoenvironment of deposition. Fifty ditch cutting samples within the interval of 2179-3523 m were analyzed. The acid methods of sample preparation for palynofacies analyses were followed. The result of the analyses yielded low to abundant occurrences of pollen and spores with an abundance of small, medium and large sizes of palynomacerals 1 and 2, few occurrences of palynomacerals 3 and 4. The lithology consists of the alternation of shale and sandstone units with few intercalations of argillaceous sandstone units, indicating that the studied interval belongs to the Agbada Formation. The studied intervals were dated to the middle Miocene to late Miocene, based on the recovered age diagnostic marker species such as Zonocostatites ramonae, Multiareolites formosus, Verrutricolporites rotundiporus, Crassoretitriletes vanraadshoveni and Racemonocolpites hians. Two interval range palynostratigraphic zones: Multiareolites formosus - Zonocostatites ramonae, Verrutricolporites rotundiporus - Crassoretitriletes vanraadshoveni and a taxon range zone: Ainipollinite verus zone were proposed. Paleoenvironmental interpretation was based on the palynofacies association and the lithology which revealed that the stratigraphic interval studied was deposited in the Coastal-deltaic (marginal marine) environments.
\end{abstract}

Keywords: palynofacies, paleoenvironment, palynostratigraphic zone, Ida- 4 well

\section{INTRODUCTION}

Palynofacies could be described as the entire acid resistant organic matter (palynological matter) element in a sedimentary deposit. The term was first introduced by Combaz (1964) to describe the total microscopic image of the organic components in sedimentary rock samples. Subsequent authors have assigned different names to the organic components such as organic matter (Gehmann 1962, Lorente 1990, Batten \& Stead 2005), palynodebris (Boulter \& Riddick 1986, Van der Zwan 1990, Boulter 1994) and kerogen or palynomacerals
(Oyede 1992, Tyson 1995, Araujo et al. 1998, Thomas et al. 2015). Palynofacies was defined by Tyson (1995) as a body of sediment containing a distinctive assemblage of palynological organic matter thought to reflect a specific set of environmental conditions or to be associated with a characteristic range of hydrocarbon-generating potential. Batten \& Stead (2005) defined palynofacies (palynological facies) generally to mean organic matter that is recovered from a rock or unconsolidated sediment by the standard palynological processing technique of digesting a sample in $\mathrm{HCl}$ and/or HF. Every sedimentary deposit containing 
organic matter have an associated palynofacies, which could be miospores (small spores and pollen grains), prasinophyte algal bodies, dinoflagellate cysts, acritarch, foraminifera linings, structured fragments such as cuticles and wood tissues (phytoclasts or fragments of plants) and unstructured materials having an amorphous appearance. These organic matters are common, occurring in abundance in both continental and marine deposits. They are equally resistant to acid, high temperature and pressure, microbial decay and solutioning in water. Palynofacies analysis has several stratigraphic applications such as in chronostratigraphy, biostratigraphy and sequence stratigraphy. Its stratigraphic application is very useful on a local scale for the fine correlation of reservoir units within oil-fields and to some extent on scale especially in areas or within successions which more conventional boistratigraphic markers are scarce or lacking (Batten \& Stead 2005). Palynofacies analysis is useful in the interpretation of the processes controlling deposition. It also provides the basis for the reconstruction of paleogeography, paleoecology, paleoenvironment and paleoclimate.

The most comprehensive contribution to the knowledge on the palynology of the Niger Delta was made by Germeraad et al. (1968). Their study was based on the palynomorph assemblages of the Tertiary sediments of three tropical areas: parts of South America, Asia and Africa (Nigeria). They established nine pantropical zones using quantitative base and top occurrence (numeric method) of diagnostic species such as Echitricolporite spinosus, Crassoretitriletes vanradshoveni, Magnastrites howardi, Verrucatosporites usmensis, Monoporites annulatus and Proxapertites operculatus. Evamy et al. (1978) established twenty-nine informal palynological zones of the Niger Delta using alphanumeric coding method which seems to form the background information for in-house zonal scheme of Shell Petroleum Development Company. Oboh et al. (1992) carried out palynological interpretation of the palaeoenvironments of Miocene strata of the well Igbomotoru-1, Niger Delta. They used the lithology and the abundance or scarce occurrence of Zonocostites ramonae in the samples to interpret the environment of deposition to be largely transitional with marine influence. Therefore, this work is aimed at carrying out the palynofacies analyses of the ditch cuttings retrieved from Ida-4 well in order to establish the palynostratigraphic zonation, biochronology and paleoenvironment of deposition of the strata penetrated by the well.

\section{Location of the studied well and the geology of the Niger Delta Basin}

The Niger Delta lies between latitudes $4-6^{\circ} \mathrm{N}$ and longitudes $3-9^{\circ} \mathrm{E}$ in the southern part of Nigeria (Fig. 1). The coordinates that describe the locations of Ida- 4 well are $4.82^{\circ} \mathrm{N}$ and $6.86^{\circ} \mathrm{E}$ in the Coastal Swamp Depobelt of the Eastern Niger Delta Basin (Fig. 1). Short \& Stauble (1967) recognized three formations in the subsurface of the Niger Delta. In ascending order, these formations are; the Akata, Agbada and Benin formations. The Akata Formation generally consists of open marine and prodelta dark grey shale with lenses of siltstone and sandstone. The Agbada Formation consists of cyclic coarsening-upward regressive sequences. The coarsening upward sequences are composed of shales, siltstones, and sandstones which include delta front and lower delta plain deposits (Weber 1971). The Benin Formation comprises a succession of massive poorly indurated sandstones, thin shales, coals, and gravels of continental to upper delta plain origin. The three formations were deposited in continental, transitional and marine environments (Ola \& Adewale 2014). Doust \& Omatsola (1990) recognized depositional belts in the Niger Delta, these are: The Northern Delta, Greater Ughelli, Central Swamp, Coastal Swamp, and Offshore depobelts (Fig. 1). They are distinguished by their age and most importantly their location.

\section{METHODS}

The materials used for this study include ditch cutting samples and wireline logs of the Ida- 4 well and were provided by Chevron Nigeria Plc. All the laboratory facilities required were made available by Crystal Age Limited, Lagos, where the laboratory analyses were carried out. 


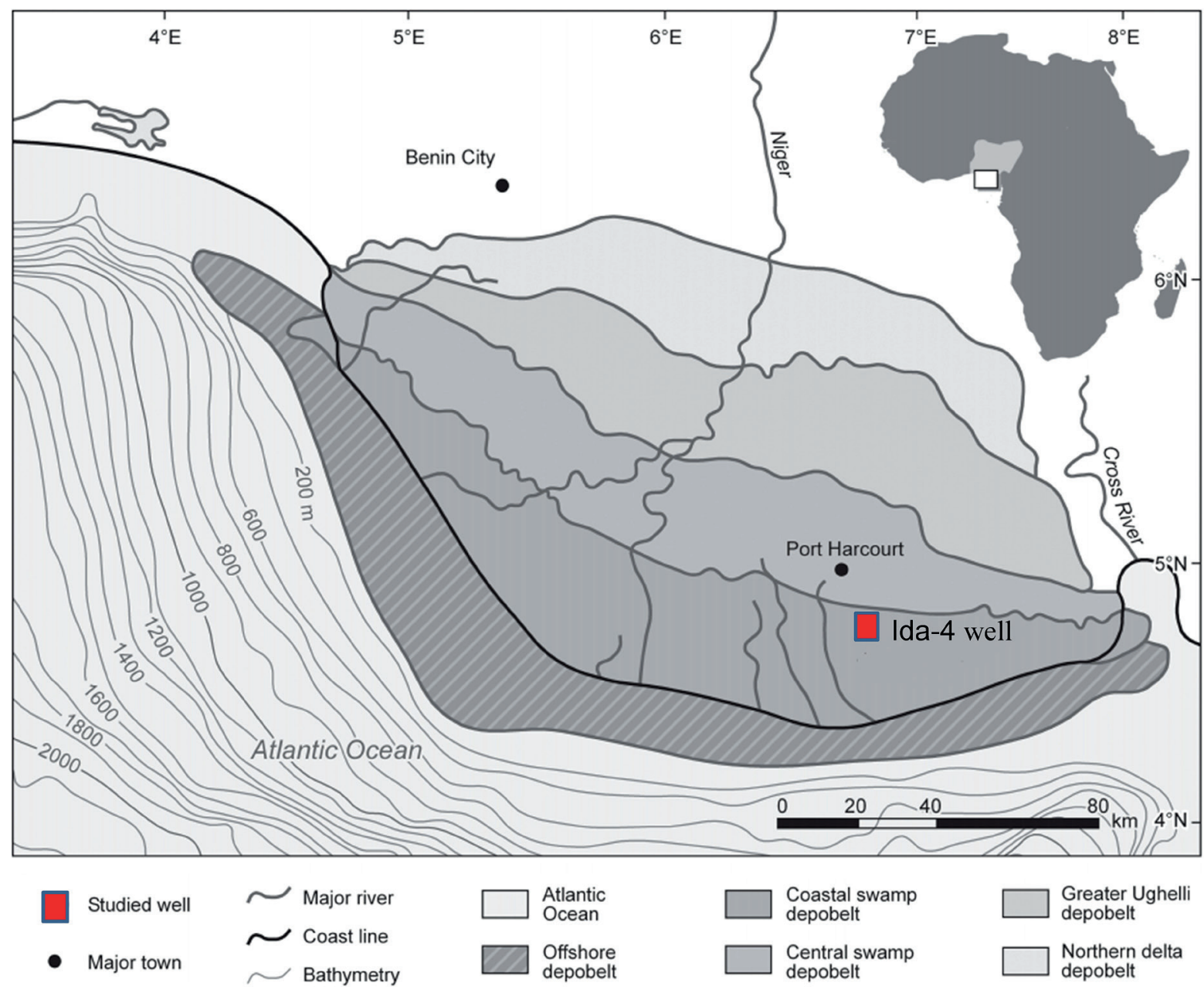

Fig. 1. Location of the studied well on the Niger Delta Basin Depobelt map (modified after Okosun \& Chukwuma-Orji 2016)

\section{Lithologic description}

Lithologic description of the stratigraphic intervals studied was done by physical observation and a chart for the textural analysis of clastic sediments. Fissile or platy samples indicate shale, while samples with fine to coarse grained sizes indicate sandstone units. The description was enhanced by the Gamma-ray log, since high and low values of Gamma log signify shale and sandstone lithologies, respectively (Fig. 2) (Adegoke 2002, Olayiwola \& Bamford 2016).

\section{Sample preparation for organic matter recovery}

The acid method of sample preparation for organic matter recovery (Traverse 2007) was followed with modifications. Fifty ditch cutting samples from the Ida- 4 well within the interval of $2152-3523 \mathrm{~m}$ were analyzed. Fifteen grams of each sample were treated with $10 \% \mathrm{HCl}$ under a fume cupboard for the complete removal of carbonates present in the samples. This was followed by complete neutralization with distilled water. Then HF (40\% concentration) was added to the samples which were left for 24 hours to ensure a complete dissolution of the silicates present in the samples. Thereafter, the HF was carefully decanted, followed by complete neutralisation with distilled water in order to remove fluoro-silicate compounds usually formed from the reaction with HF. Sieving and separation were performed using a Brason Sonifier 250 to filter away the remaining inorganic matter (silicates, clay, and mud) and heavy minerals to recover organic matters. A Brason Sonifier is an electric device used with the aid of $5 \mu \mathrm{m}$ sieve and it operates a sonic vibration to filter inorganic matter 
and heavy minerals. The sieved residue was given controlled oxidation using concentrated nitric acid $\left(\mathrm{HNO}_{3}\right)$. For palynomacerals recovery, the same procedure for sample preparation for palynomorphs recovery was followed, except that the oxidation process with $\mathrm{HNO}_{3}$ was omitted in order not to bleach the palynodebris. The recovered organic matters were uniformly spread on arranged cover slips of $22 / 32 \mathrm{~mm}$ and were then allowed to dry for mounting. The mounting medium used for permanent mounting of the cover slip onto glass slide was Loctite (Impruv) and was dried with natural sunlight for 5 minutes.

Both palynology and palynomaceral slides were examined under an Olympus Binocular light transmitted microscope. The palynomaceral slides were subjected to quantitative analysis of different types of palynomacerals (type 1,2,3, and 4) as well as structureless organic matter (SOM). Identification of palynomorph and palynomacerals was made using palynological albums and the published works of previous researchers (Germeraad et al. 1968, Oyede 1992, Ige 2009, Bankole 2010, Ige et al. 2011, Ajaegwu et al. 2012, Durugbo \& Aroyewun 2012, Ola \& Adewale 2014, Thomas et al. 2015).

\section{RESULTS}

\section{Lithology}

The lithology of the studied interval consists of alternating shale/mudstone and sandstone unites with few intercalations of argillaceous sandstone (sandy shale and siltstone) units (Fig. 2 on the interleaf). This suggests that the studied interval belongs to the Agbada Formation. The shale/mudstones are mostly grey to brownish grey in colour, moderately hard to hard, platy to flaggy in appearance. The sandstones are predominantly milky white, coarse to fine grained, angular to subangular to rounded, and poorly to well sorted in texture (Fig. 3).

\section{Palynology}

The result of palynofacies analysis is presented in the palynomorph and palynomacerals distribution chart of the Ida- 4 well (Fig. 2). The chart presents the different palynomorph taxa and types of palynomacerals encountered at the different studied depth intervals. Palynological analysis yielded a significant number of pollen and spores with low to moderate diversity. Pollen and spores were dominant. The results of this study are similar to that obtained in the palynofacies studies of Ida- 5 and Ida-6 wells Niger Delta Basin (Chukwuma-Orji et al. 2017a, 2017b). Photomicrographs of some of the recovered forms are illustrated in Figure 4.

The spores recorded include the species of Laevigatosporites sp., Verrucatosprites sp., Aletisporites sp., Cyperaceaepollis sp., Lycopodium sp., Selaginella myosorus, Pteris sp., Crassoretitriletes vanraadshoveni, Acrostichum aureum and Magnastriatites howardi.

The pollen species recovered were: Zonocostites ramonae, Monoporites annulatus, Racemonocolpiteshians, Elaies guineensis, Praedapollisflexibilis, Striatricolpites catatumbus, Retibrevitricolporites protudens, Pachydermites diederixi, Psilatricoloporites crasssus, Retitricolporites irregularis, Peregrinipollis nigericus, Gemamonocolpites sp., Multiareolites formosus, Verrutricolporites rotundiporus, Chenophodipollis sp., Numulipollis neogericus, Canthium sp., Coryius sp., sapotaceae, Psilatricolporites sp., Alnipollinites verus, Podocarpus milanjianus, Podocarpidites sp. and Retitricolporites sp. The algal cysts present are Botryococcus braunii and no dinoflagellate cyst was recovered.

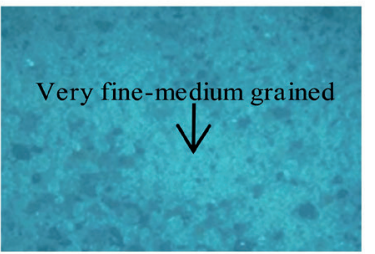

1

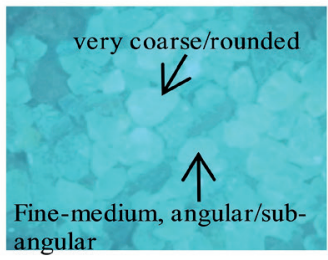

2

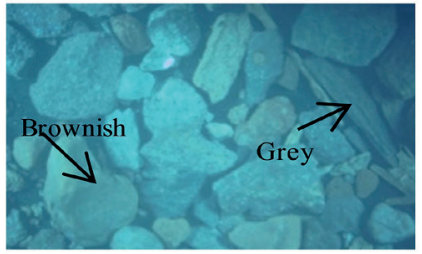

3

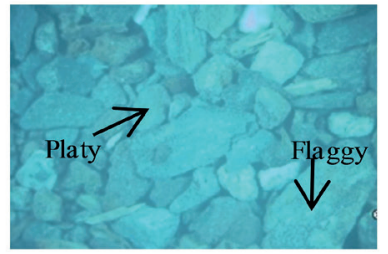

4

Fig. 3. Some photomicrographs of the ditch cutting samples ( $\times 400): 1$ - milky white, very fine to medium-grained, well sorted sand; 2 - milky white, fine to medium-grained, coarse to very coarse-grained, angular to rounded, poorly sorted sand; 3 - grey to brownish shale; 4 - platy to flaggy shales 


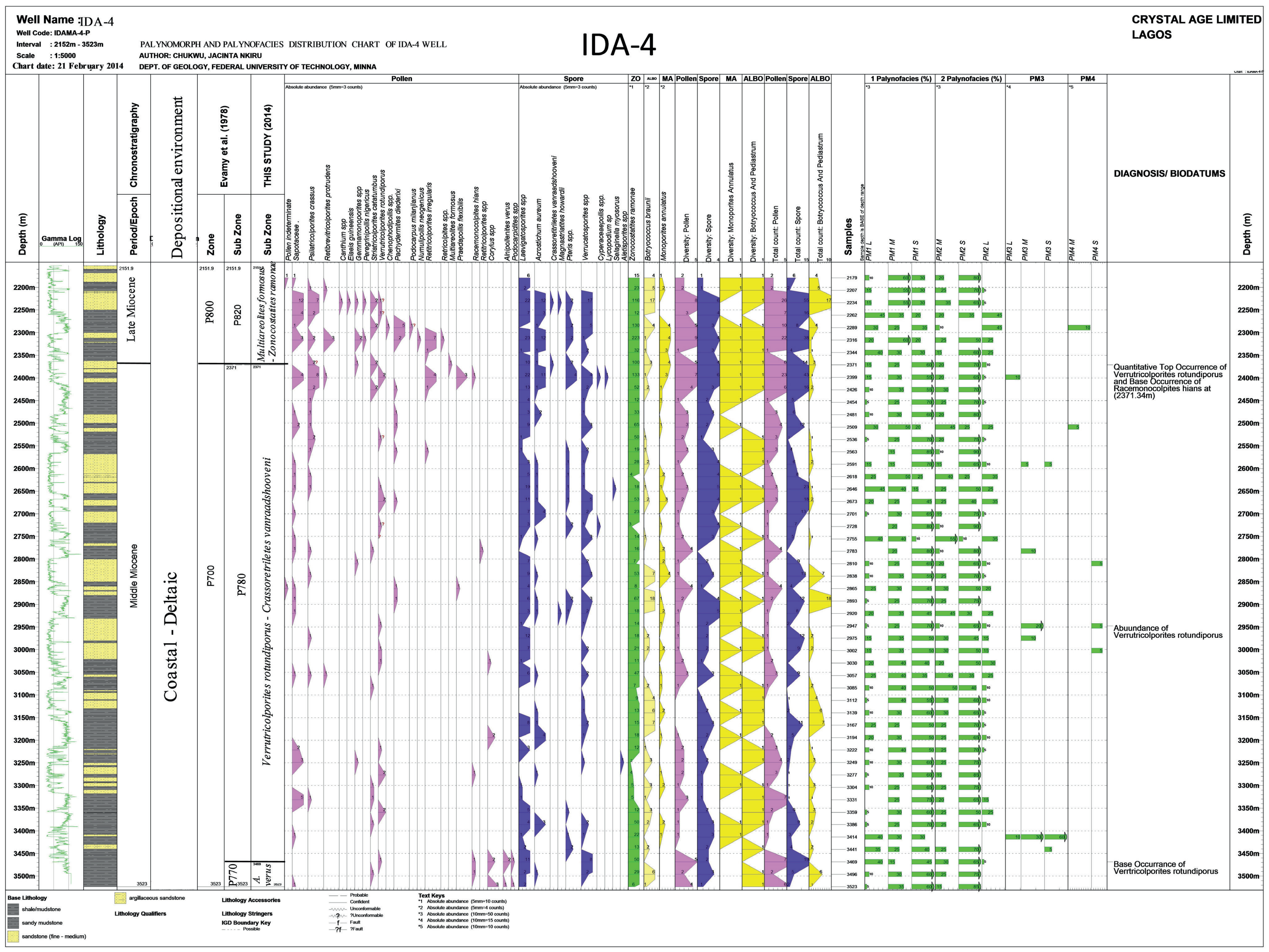




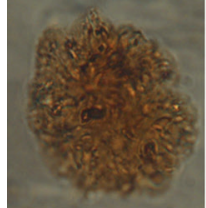

1

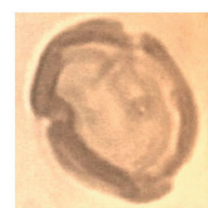

7

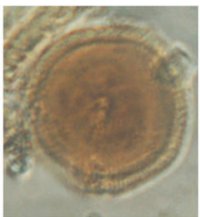

13

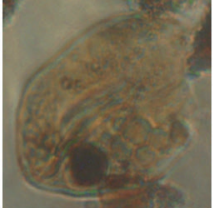

2
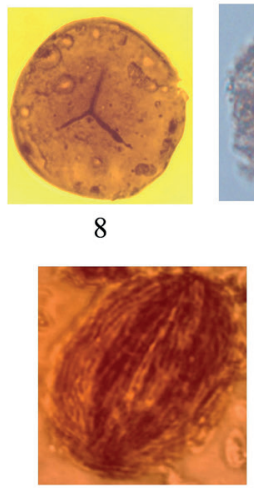

14

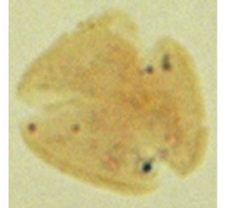

3
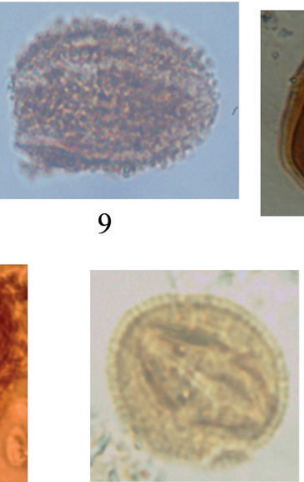

15

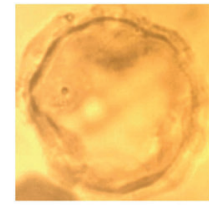

4

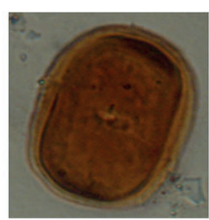

10

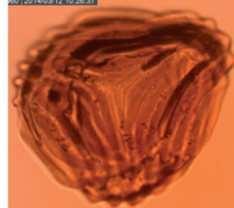

5

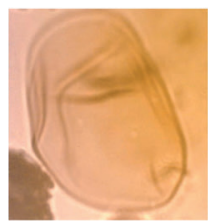

11

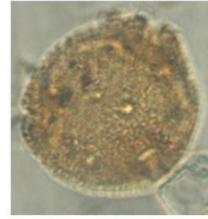

6

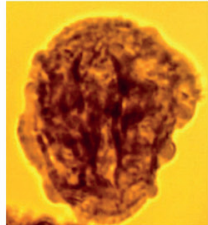

12

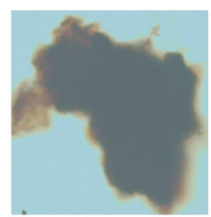

18

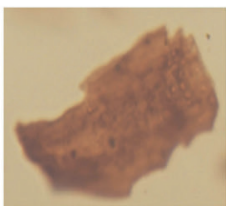

22

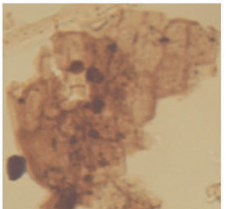

26

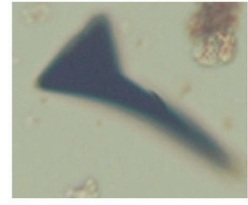

30

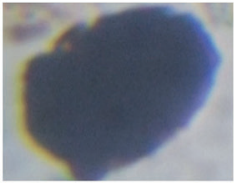

19
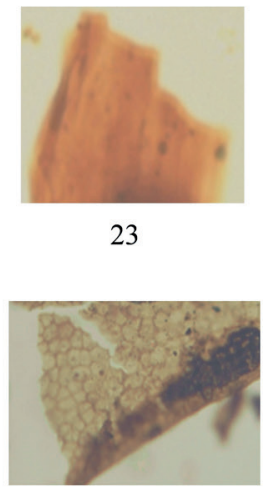

27

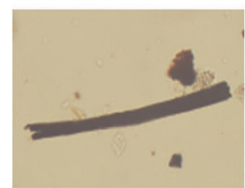

31

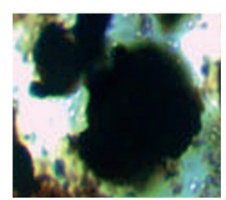

20

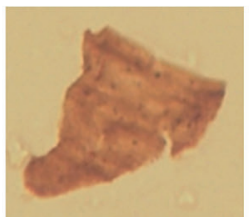

24

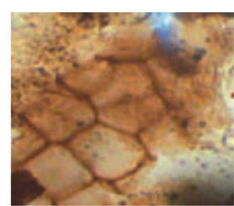

28

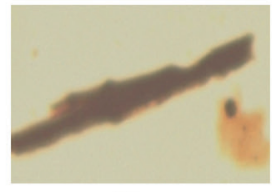

32

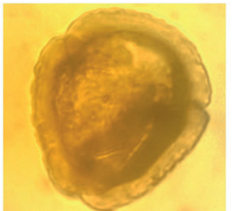

16

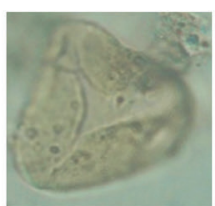

17

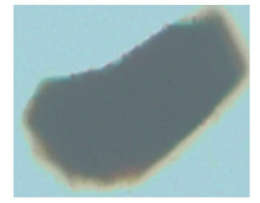

21

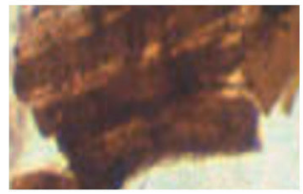

25

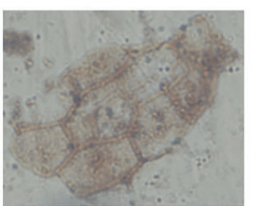

29

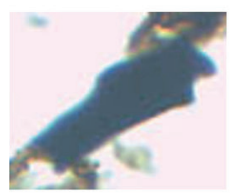

33

Fig. 4. Palynomorphs and palynomacerals recovered from the studied wells (× 400): 1 - Botryococcus braunii Kutzing 1849; 2 - Gemmamonoporites sp. Van Der Hammen and Garcia De Mutis 1965; 3 - Retitricolporites sp.; 4 - Monoporites annulatus Van Der Hammen 1954; 5 - Magnastriatites howardii Germeraad et al., 1968; 6 - Retibrevitricolporites protrudens Legoux 1978; 7 - Zonocostites ramonae Germeraad et al. 1968; 8 - Acrostichum aureum Oloto 1994; 9 - Racemonocolpites hians Bankole et al. 2014; 10 - Multiareolites formosus Van Der Hammen 1954; 11 - Laevigatosporites sp. Oloto 1994; 12 - Peregrinipollis nigericus Legoux 1978; 13 - Numulipollis neogenicus Durugbo et al. 2010; 14 - Striaticolpites catatumbus Germeraad et al. 1968; 15 - Verrutricolporites rotundiporus Vander Hammen and Wijstra 1964; 16 - Psilatricolporites crassus Vander Hammen and Wijstra 1964; 17 - Elaies guineensis; 18-21 - palynomaceral 1; 22-25 - palynomaceral 2; 26-29 - palynomaceral 3; 30-33 - palynomaceral 4 


\section{Palynomacerals}

The palynomacerals analysis yielded abundant records of palynomercerals 1 and 2, few occurrences of palynomacerals 3 and 4 and no record of structureless organic matter (SOM) (Figs. 2, 4).

\section{Palynomaceral 1 (PM 1)}

In this study, the observed palynomaceral 1 appeared to be orange-brown to dark-brown in colour, opaque, irregular in shape, structureless and varies in preservation (Fig. 4). Oyede (1992) described palynomaceral 1 as particulate organic matter (alginite) that is orange-brown to darkbrown in colour, dense in appearance, irregular in shape, structureless and varies in preservation. It is heterogeneous and of higher plant in origin and some are products of exudation processes such as the gelification of plant debris in the sediments. Palynomaceral 1 includes small, medium and large sizes of flora debris, humic gel-like substances and resinous cortex irregularly shaped materials (Oyede 1992, Thomas et al. 2015).

\section{Palynomaceral 2 (PM 2)}

The PM 2 observed in this study is irregular in shape, brown-orange in colour, and platy in structure (Fig. 4). According to Oyede (1992) palynomaceral 2 (exinites) is usually brown-orange colour, structured but irregular in shape. It encompasses platy like structured plant materials (leaves, stems or small rootlet debris), algae debris and a few amounts of humic gels and resinous substances. It is more buoyant than palynomaceral 1 because of its thinner lath-shaped character.

\section{Palynomaceral 3 (PM 3)}

The PM 3 observed in this study is generally translucent and contained stomata, pale to brown in colour and is irregular in shape (Fig. 4). Oyede (1992) stated that PM 3 (vitrinite) is pale, relatively thin and irregularly shaped and occasionally contains stomata. Also, it includes structured plant material, mainly of cuticular origin and degraded aqueous plant material. It is more buoyant than palynomaceral 2 (Thomas et al. 2015).

\section{Palynomaceral 4 (PM 4)}

The observed PM 4 in this study varies from black to dark brown in colour, with blade or needle like shapes (Fig. 4). Oyede (1992) described PM 4 (inertnite) as being black to charcoal black in colour. Also, it is equidimensional, blade or needle shaped material. It is uniformly opaque and structureless but may occasionally show a cellular structure. The components of this palynomaceral are of different origins and they include compressed humic gels, charcoal and geothermally fusinized material. Blade-shaped palynomaceral 4 is extremely buoyant and resistant to degradation. Thus, they are often transported over long distances (Oyede 1992, Thomas et al. 2015). A concentration of PM 4 characterizes a high energy environment.

\section{DISCUSSION}

\section{Palynostratigraphic zonations and age determination}

The palynostratigraphic zones proposed in this study were based on the international stratigraphic guide - an abridged version of Murphy \& Salvador (1999). The works of Germeraad et al. (1968), Evamy et al. (1978), Oboh et al. (1992), Ige (2009), Bankole (2010), Aturamu \& Ojo (2015) and Olayiwola \& Bamford (2016) were also consulted. Age diagnostic marker species were used to determine the age of the studied interval in the well. Three biozones were proposed in the studied wells: Multiareolites formosus - Zonocostites ramonae, Verrutricolporites rotundiporus - Crassoretitriletes vanraadshoveni and Alnipollinite verus zones.

\section{Multiareolites formosus - Zonocostites ramonae zone (Interval zone)}

Stratigraphic interval: 2179-2371 m.

Definition: The top of the zone is defined by the first downhole occurrence (FDO) of Zonocostatites ramonae at $2179 \mathrm{~m}$ while the base is marked by the last downhole occurrence (LDO) of Multiareolites 
formosus and Crassoretitriletes vanraadshoveni at $2371 \mathrm{~m}$.

Characteristics: The assemblages of palynomorphs taxa that characterize this zone include Zonocostites ramonae, Crassoretitriletes vanraadshoveni, Numulipollis neogericus, Multiareolites formosus and Retibrevitricolporites protrudens. Other taxa occurring within the zone are sapotacea, Psilatricoloporites crasssus, Peregrinipollis nigericus, Laevigatosporites sp., Verrucatosprites sp., Aletisporites sp., Pteris sp., Acrostichum aureum and Magnastriatites howardi.

Age: The zone is dated to the late Miocene because of the presence of Crassoretitriletes vanraadshoveni, Multiareolites formosus and Peregrinipollis nigericus.

Remark: The zone is equivalent to the P800 zone and P820 subzone of Evamy et al. (1978). The zone is marked by the very rich recovery of Zonocostites ramonae, Monoporites annulatus, Botryococcus braunii and Laevigatosporites sp. There is a single occurrence of Podocarpus milanjianus within the zone. The base occurrence of this species marks the late Miocene - early Pliocene boundary (Morley 1997). Its occurrence within the zone could have resulted from caving in and mixing of rock cuttings during drilling. Also occurring within the zone is indeterminate pollen, which could probably be reworked specimens since it is not well preserved.

\section{Verrutricolporites rotundiporus - Crassoretitriletes vanraadshoveni zone (Interval zone)}

Stratigraphic interval: 2371-3469 m.

Definition: The top of the zone is defined by the last downhole occurrence (LDO) of Crassoretitriletes vanraadshoveni, Multiareolites formosus and base regular occurrence of Gemamonocolpites $\mathrm{sp}$ at $2371 \mathrm{~m}$ while the base is marked by the last downhole occurrence of Verrutricolporites rotundiporus at $3469 \mathrm{~m}$.

Characteristics: The zone is characterized by the presence and lowermost documented occurrence of Racemonocolpites hians, Retibrevitricolporites protudens, Pachydermites diederixi, Psilatricoloporites crasssus, Gemamonocolpites sp.,
Multiareolites formosus, Verrutricolporites rotundiporus and sapotaceae within the zone. The occurrence of Zonocostites ramonae and Monoporites annulatus are rich within this zone.

Age: The zone is dated to the middle Miocene because taxa such as Verrutricolporites rotundiporus, Retibrevitricolporites protudens, and Racemonocolpites hians are diagnostic of the middle Miocene.

Remark: The is equivalent to the P700 zone and P780 subzone of Evamy et al., (1978).

\section{Alnipollinite verus zone (Taxon-range zone)}

Stratigraphic interval: 3469-3523 m.

Definition: The top and base of the zone is defined by the first and last downhole occurrence of $\mathrm{Al}$ nipollinite verus at the depth of 3469-3523 $\mathrm{m}$ respectively. The first and last downhole occurrence of Podocarpidites sp. also marks the top and base of the zone.

Characteristics: The zone is characterized by the lowermost documented occurrence of Striatricolporites catatumbus, Laevigatosporites sp., sapotaceae, Zonocostates ramonae, Acrostichum aureum, Monoporites annulatus and Racemonocolpites hians. Retibrevitricolporites protrudens - a species with an age range of Oligocene to Pliocene has its LOD within the zone.

Age: The zone is dated to the middle Miocene. The stratigraphic position of the zone and the presence of the above-mentioned taxa that defined and characterized the zone aided its age assignment.

Remark: The zone is equivalent to the P700 zone and P770 subzone of Evamy et al. (1978).

\section{Correlation of the established palynostratigraphic zones with the Niger Delta Cenozoic chart}

The established zones of this study and their $\mathrm{P}$ zones equivalent of Evamy et al. (1978) are correlated with the Niger Delta Cenozoic chart (Fig. 5). The correlation reveals that the studied well is located in the Coastal Swamp Depobelt. It also confirms the assigned age of the studied interval to be the middle to late Miocene. 


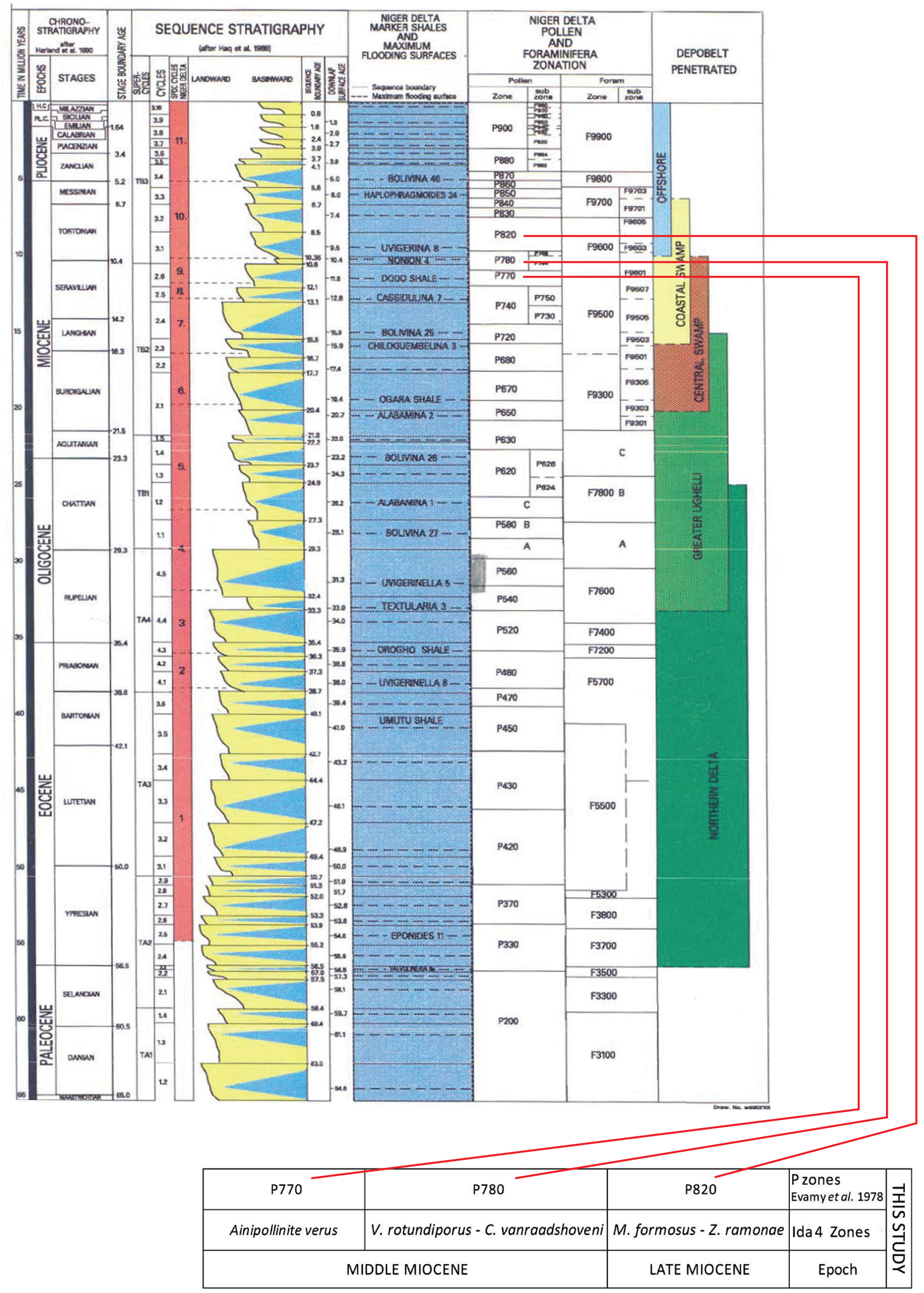

Fig. 5. Palynostratigraphic zones correlation with the Niger Delta Cenozoic chart 


\section{Paleoenvironment of deposition}

This involves the periodic changes in the depositional environment over geologic time. Evaluation of paleoenvironment of deposition is essential because different depositional environments give rise to reservoirs with different qualities and characteristics such as porosity, permeability, heterogeneity and architecture.

Inference of the paleodepositional environments of the studied wells was made based on the following criteria:

- The nature of organic matter (palynomercerals) recovered in the studied interval. The terrestrial/coastal and marine depositional environments have been distinguished to have distinctive and characteristic palynofacies (Oyede 1992, Thomas et al. 2015). The terrestrial/coastal environments are characterized by poorly sorted palynomacerals 1 and 2 , absence of dinocysts and common to abundant occurrence of fungal spores, while a marine environment is characterized by a good sorting of organic matter predominantly small to medium, common to abundant palynomacerals 1 and 2, some needle-shaped to lath-shaped palynomaceral 4 and presence of dinocysts and or foraminifera linings (Oyede 1992).

- Association of environmentally restricted diagnostic species such as Zonocostites ramonae, Monoporites annulatus, Pachydermites diederixi, Psilatricoloporites crasssus, Laevigatosporites sp. and Botryococcus braunii.

Based on the above-mentioned criteria, a lower delta plain to delta front and prodelta (subaerial delta to subaqueous delta plains) environment within a coastal-deltaic environment of deposition have been inferred for the sediments encountered in the analyzed intervals of the Ida- 4 well (Tab. 1, Fig. 6).

The interval $2179-2800 \mathrm{~m}$, in Ida- 4 well was delineated to have been deposited in the lower delta plain environment. The lower delta plain is equivalent to a fore shore and fluvio-marine environment (Fig. 6). The reasons for this deduction are:
- The intervals are characterized by high representations of mangrove, freshwater swamp and rainforest swamp taxa, freshwater algae, savannah and montane taxa such as Zonocostites ramonae, Monoporites annulatus, Striatricolpites catatumbus, Retibrevitricolporites protudens, Pachydermites diederixi, Psilatricoloporites crasssus, Verrutricolporites rotundiporus, Botryococcus braunii, Acrostichum aureum, Pachydermites diederixi and Laevigatosporites sp.

- The abundant records of palynomacerals 1 and 2 indicate a coastal deltaic environment of deposition with an influx of fresh water from the moderate quantities of Botryococcus braunii and Laevigatosporites sp. recorded within the interval. - Aggradational, progradational and retro gradational log motifs characterize the sands (intercalated by shales) in the interval suggest their deposition as channel/bar complexes in a delta plain - delta front setting. Lithologically, the sands are milky white, very fine to medium-grained, occasionally coarse to very coarsegrained/granule-sized, poorly to well sorted and sub-angular to sub-rounded. The shales are reddish brown to grey, silty, platy and moderately soft to moderately hard. These criteria indicate deposition in lower deltaic plain environments.

Similarly, the interval $2800-2885$ m was delineated to have been deposited in a delta front (inner neritic) environment of deposition. The criteria for this deduction are:

- The intervals are characterized by increased representation of montane taxa such as Monoporite annulatus, reduced occurrences of mangrove, freshwater swamp and rainforest swamp taxa compared to the above intervals.

- The palynomacerals 1 and 2 that occur are more of large and medium sizes than the small size.

- The sands and shale intercalations in this interval are characterized by blocky/aggradational log motifs (slightly serrate cylinder on funnel-shaped log character); suggesting their deposition as channels/channel fills in a delta front setting.

Table 1

Environment of deposition in Ida-4

\begin{tabular}{|c|c|}
\hline Ida-4 well intervals $[\mathbf{m}]$ & Inferred depositional environment \\
\hline $2179-2800$ & subaerial delta (lower delta plain/fore shore) \\
\hline $2800-2885$ & subaqueous delta (delta front/lower shore face) plain \\
\hline $2885-3523$ & subaqueous delta (delta front to prodelta) plain \\
\hline
\end{tabular}




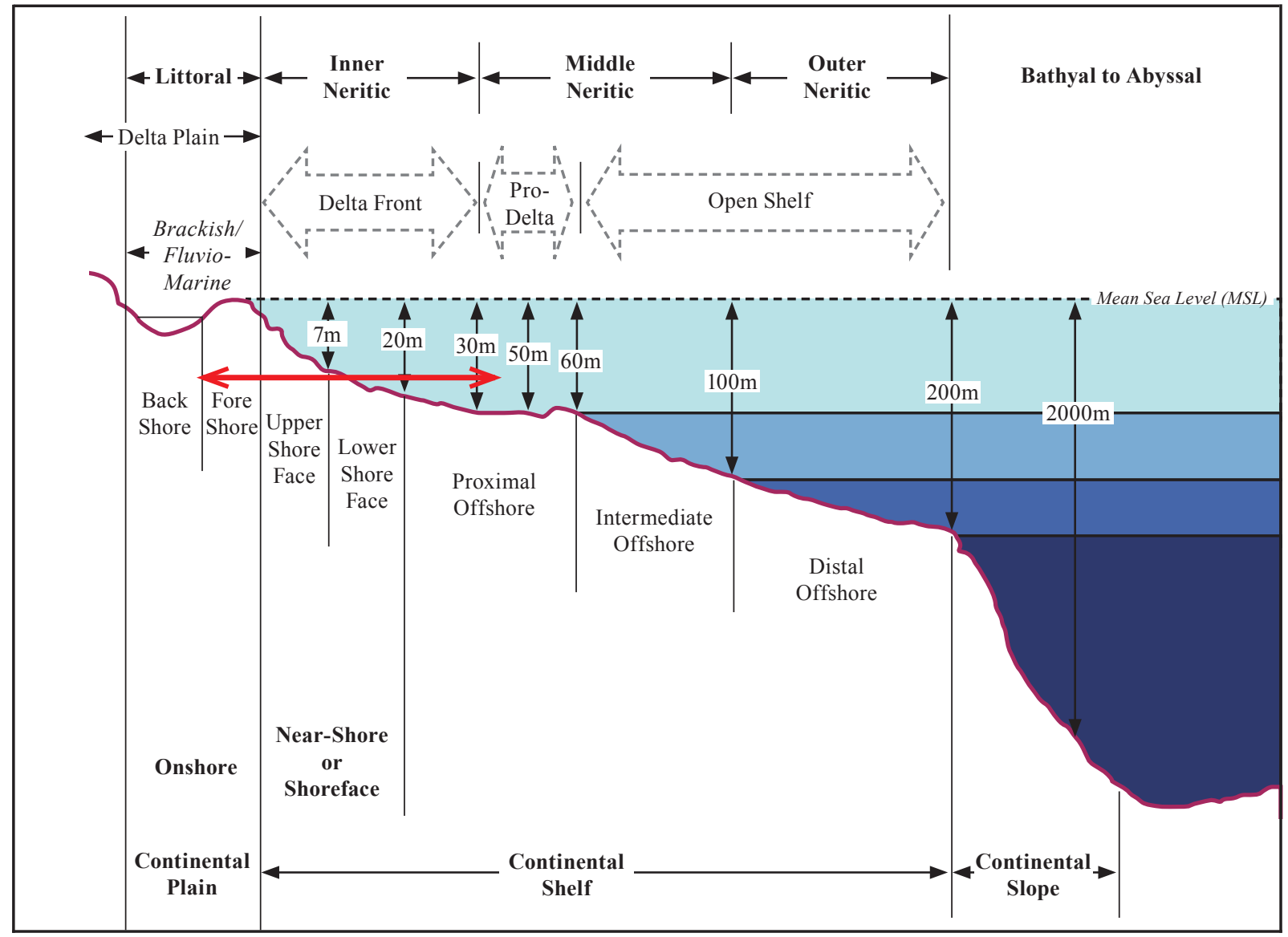

key

Inferred depositional environments of Ida- 4 well

Fig. 6. Depositional environments and bathymetric ranges used in paleoenviromental interpretation (modified after Ijomah et al. 2016)

The lowermost segment: $2885-3523 \mathrm{~m}$ of the Ida- 4 well is also inferred to have been deposited in delta front to prodelta environment of deposition. The reasons for this inference are:

- The intervals are characterized by moderate representation of mangrove, freshwater swamp and rainforest swamp taxa Zonocostites ramonae, Monoporites annulatus, Striatricolpites catatumbus, Retibrevitricolporites protudens, Pachydermites diederixi, Psilatricoloporites crasssus, Verrutricolporites rotundiporus, Botryococcus braunii, Acrostichum aureum, Laevigatosporites sp. and Pachydermites diederixi, rare to non-representation of savannah and montane taxa suggesting subaqueous delta environment.
- They are characterized by moderate to good sorting of palynomacerals 1 and 2, predominantly common to abundant small to medium sizes.

- The lithology is mostly shaly intercalated with sandstone units. The sandstone units exhibited multiserrate funnel, cylinder/subtle bellshaped Gamma Ray log profiles interpreted as subaqeous mouth bars and distributary channel deposits indicates prograding shoreline.

\section{CONCLUSION}

Palynofacies were carried out on the strata penetrated by the Ida- 4 well using the ditch cuttings and gamma ray log provided by Chevron Nigeria 
Limited. Fifty ditch cutting samples within the interval of 2152-3523 m, in the Ida- 4 well were analysed. The analysis yielded low to abundant recovery of pollen and spores, small to large sizes of palynomacerals 1 and 2, few occurrences of palynomacerals 3 and 4 . The lithology showed the alternation of shale and sandstone units with few intercalations of argillaceous sandstone units, indicating the Agbada Formation. The alternation of shale and sandstone units forms good targets in petroleum exploration because they act as seal and reservoir rock units. The studied intervals were dated to the middle Miocene to late Miocene based on the recovered age diagnostic marker species such as Multiareolites formosus, Verrutricolporites rotundiporus, Crassoretitriletes vanraadshoveni and Racemonocolpites hians. Three palynostratigraphic zones were established in the three wells using the international stratigraphic guide for establishment of biozones. Multiareolites formosus - Zonocostites ramonae, Verrutricolporites rotundiporus - Crassoretitriletes vanraadshoveni and Ainipollinite verus zones were established. The three zones proposed are equivalent to the P770, P780 and P820 of Evamy et al. (1978). These were correlated to the Niger Delta chronostratigraphic chart. The correlation shows that the age of the studied interval of the well is the middle to late Miocene and falls in the Coastal Swamp Depobelt of the Niger delta. The proposed palynostratigraphic zones of this study could contribute to the harmonization of the $\mathrm{Ni}$ ger Delta floral biozonation scheme. Coastal-deltaic (lower delta plain to prodelta) environments of deposition have been inferred for the studied interval based on the lithology and the palynofacies association.

\section{REFERENCES}

Adegoke O.S., 2002. High resolution biostratigraphy, sequence stratigraphy and 3-D modeling. Indispensable tools for E \& P activities in the New Millenium. Nigerian Association of Petroleum Explorationist Bulletin, 16, $1,46-65$.

Ajaegwu N.E., Odoh B.I., Akpunonu E O., Obiadi I.I. \& Anakwuba E.K., 2012. Late Miocene to Early Pliocene Palynostratigraphy and Palaeoenvironments of ANE-1 Well, Eastern Niger Delta. Nigeria Journal of Mining and Geology, 48, 31-43.

Araujo C.V., Condé V.C., Botelho-Neto J., Pedrão E. \& Conceição J.C.J., 1998. Palynofacies in a sequence stratigraphy context, an example of an upper Aptian section from
Almada Basin, Brazil. [in:] The American Association of Petroleum Geologists, International Conference and Exhibition, abstracts, 82, 1886-1887.

Aturamu A.O. \& Ojo A.O., 2015. Integrated biostratigraphic analysis of the Agbada Formation (Nep-1 Well) offshore, Eastern Niger-Delta Basin, Nigeria. Australian Journal of Biology and Environment Research, 2, 1-14.

Bankole S.I., 2010. Palynology and stratigraphy of three deep wells in the Neogene Agbada Formation, Niger Delta, Nigeria. Implications for petroleum exploration and paleoecology. Technische Universität, Berlin [Ph.D. thesis].

Batten D.J. \& Stead D.T., 2005. Palynofacies analysis and its stratigraphic application. [in:] Koutsoukos E.A.M. (ed.), Applied stratigraphy, Springer, Netherland, 203-226.

Boulter M.C., 1994. An approach to a standard terminology for palynodebris. [in:] Traverse A. (ed.), Sedimentation of Organic Particles, Cambridge University Press, Cambridge, 199-216.

Boulter M.C. \& Riddick A., 1986. Classification and analysis of palynodebris from the Palaeocene sediments of the Forties Field. Sedimentology, 33, 871-886.

Chukwuma-Orji J.N., Okosun E.A., Alkali Y.B., Taiwo O.M. \& Fadiya L.S., 2017a. Palynofacies analysis of Ida 5-well, Niger Delta Basin, Nigeria. Nigeria Journal of Engineering and Applied Sciences, 4, 95-112.

Chukwuma-Orji J.N., Okosun E.A., Goro I.A. \& Waziri S.H., 2017b. Palynofacies, sedimentology and palaeoenvironment evidenced by studies on IDA- 6 well, Niger Delta, Nigeria. Paleoecology of Africa, 34, 87-105.

Combaz A., 1964. Les palynofacies. Revue de Micropaléontologie, 7, 205-218.

Doust H. \& Omatsola E., 1990. Niger Delta. [in:] Edwards J.D. \& Santogrossi P.A., Divergent/Passive Margin Basins, AAPG Memoir, 48, American Association of Petroleum Geologists, Tulsa, 239-248.

Durugbo E.U. \& Aroyewun R.F., 2012. Palynology and Paleoenvironments of the Upper Araromi Formation, Dahomey Basin, Nigeria. Asian Journal of Earth Sciences, $5,50-62$.

Evamy B.D., Haremboure J., Karmerling P., Knaap W.A., Molloy F.A. \& Rowlands P.H., 1978. Hydrocarbon habitat of the Tertiary Niger Delta. American Association of Petroleum Geologists Bulletin, 62, 1-39.

Gehmann H.M. Jr., 1962. Organic matter in limestones. Geochimica et Cosmochimica Acta, 26, 885-897.

Germeraad J.J., Hopping G.A. \& Muller J., 1968. Palynology of Tertiary sediments from tropical areas. Review of Paleobotany and Palynology, 6, 189-348.

Ige O.E., 2009. A Late Tertiary Pollen record from Niger Delta, Nigeria. International Journal of Botany, 5, 203-215.

Ige O.E., Datta K., Sahai K. \& Rawat K.K., 2011. Palynological Studies of Sediments from North Chioma-3 Well, Niger Delta and its Palaeoenvironmental Interpretations. American Journal of Applied Sciences, 8, 1249-1257.

Ijomah A.K., Amajor L.C. \& Ugwueze C., 2016. Sequence Stratigraphy and Hydrocarbon Analysis of Coastal Swamp Depobelt, Niger Delta, Nigeria. Journal of Scientific and Engineering Research, 3, 285-294.

Lorente M.A., 1990. Textural characteristics of organic matter in several subenvironments of Orinoco Upper delta. Geologie en Mijnbouw, 69, 263-278. 
Morley R.J., 1997. Offshore Niger Delta palynological zonation, prepared for the Niger Delta Stratigraphic Commission. Palynova, 1, 1-6.

Murphy M.A. \& Salvador A., 1999. International Stratigraphic Guide - An abridged version, International Subcommission on Stratigraphic Classification of IUGS. International Commission on Stratigraphy, Special Episodes, 22, 255-272.

Oboh F.E., Salami M.B. \& Chapman J.L., 1992. Palynological interpretation of the palaeoenvironments of Miocene strata of the well Igbomotoru-1 Niger delta. Journal of Micropalaeontology, 11, 1-6.

Okosun E.A. \& Chukwuma-Orji J.N., 2016, Planktic Foraminiferal Biostratigraphy and Biochronology of KK-1 Well Western Niger Delta, Nigeria. Journal of Basic and Applied Research International, 17, 218-226.

Ola P.S. \& Adewale B.K., 2014. Palynostratigraphy and paleoclimate of the sequences penetrated by Meren 31 side tract-2 well, offshore Niger delta. International Journal of Geosciences, 5, 1206-1218.

Olayiwola M.A. \& Bamford M.K., 2016. Petroleum of the Deep: Palynological proxies for palaeoenvironment of deep offshore upper Miocene-Pliocene sediments from Niger Delta, Nigeria. Palaeontologia Africana, 50, 31-47.

Oyede A.C., 1992. Palynofacies in deltaic stratigraphy. Nigerian Association of Petroleum Explorationist Bulletin, 7, 10-16.

Short K.C. \& Stauble A.J., 1967. Outline of the geology of Niger Delta, American Association of Petroleum Geologists Bulletin, 51, 761-779.

Thomas M.L., Pocknall D.T., Warney S., Bentley S.J.Sr., Droxler A.W. \& Nittrouer C.A., 2015. Assessing palaeobathymetry and sedimentation rates using palynomarceral analysis: a study of modern sediments from the Gulf of Papua, offshore Papua New Guinea. Palynology, $39,3,1-24$.

Traverse A., 2007. Paleopalynology. Springer, New York. Tyson R.V., 1995. Sedimentary Organic Matter: Organic Facies and Palynofacies. Chapman \& Hall, London.

Van der Zwan C.J., 1990. Palynostratigraphy and palynofacies reconstruction of the upper Jurassic to lowermost Cretaceous of the Draugen Field, offshore mid Norway. Review of Palaeobotany and Palynology, 62, 157-186.

Weber K.J., 1971. Sedimentological aspects of oil fields in the Niger Delta. Geologie en Mijnbouw, 50, 559-576. 